\title{
COMMENTS
}

\section{DELEGATION OF POSSESSOR'S DUTY TO WARN THE EMPLOYEE OF AN INDEPENDENT CONTRACTOR OF DANGEROUS CONDITIONS ON THE LAND}

When the possessor of land employs an independent contractor to perform work on his land the possessor normally has no direct contact with the contractor's employees and often has no knowledge of their identity or number. Recognizing this situation, a few courts have absolved the possessor from liability for injury to the contractor's employees caused by latent dangerous conditions on the land if the possessor was cautious enough to warn the contractor of the dangers involved. Other courts have refused to permit a delegation of the duty to warn of latent dangerous conditions and have held the possessor liable for injury to the contractor's employees despite a warning to the contractor.

A series of decisions in Pennsylvania, where the defense of warning to the contractor has in some cases been recognized and where a considerable body of case law has evolved in the area, is illustrative. Myers $v$. Edison Elec. Illuminating Co., ${ }^{1}$ decided in 1909, seemed a harbinger of recognition of the defense in that state. Plaintiff was injured by current from uninsulated wires while working in a room in defendant corporation's power plant. The court affirmed the granting of defendant's motion for nonsuit on the ground that it was not negligent in failing to instruct plaintiff of the dangers involved in the work. After pointing out that the dangers were as obvious to the plaintiff and his employer as they were to defendant, the court stated:

"[Plaintiff] was not an employee of the defendant company, but of an independent contractor, to whom he must look if he was not properly instructed as to the dangers of the place where he was working. . . When the plaintiff was selected to work in the room where the accident occurred, which was a dangerous place, the defendant company was not aware of his selection to do the work. It was an act with which it had nothing to do, and not knowing that he was going there to work, it would be exacting entirely too much of it to require that it should have instructed him as to the dangers." 2

1. $225 \mathrm{~Pa} .387,74$ Atl. 223 (1909).

2. $225 \mathrm{~Pa}$. at $389,74 \mathrm{At1}$. at 224. See also Rugart v. Keebler-Weyl Baking Co., 277 Pa. 408, 412, 121 Atl. 198, 199 (1923). 
Several years later, however, the Pennsylvania court rejected the above language as mere dictum and held that it was not error to exclude evidence offered by the possessor of land that plaintiff's employer, an independent contractor, had noticed a defective fire escape while examining the work to be done on the premises but failed to warn plaintiff of the risks involved. ${ }^{3}$ The court justified its ruling that the evidence was inadmissible on the theory that the contractor's neglect would not relieve the possessor of his duty to warn the plaintiff. ${ }^{4}$

It was not until 1940 that Pennsylvania clearly stated its position that the possessor of land could delegate his duty to warn persons entering the land of latent dangers thereon. In Valles v. Peoples-Pittsburgh Trust Co. ${ }^{5}$ the basement wall of defendant bank had been damaged by a flood and an independent contractor, DeGiovanni, was employed to take down the wall and rebuild it. Plaintiffs, employees of the contractor, were injured when a pipe running along the damaged wall which contained ammonia to cool water in the building was accidently broken during the removal of the wall. The plaintiffs contended that, although the pipe was not shown to be defective, it was a dangerous condition and therefore the defendant was negligent in failing to warn them of its contents or stop the flow of the dangerous substance while the work was being performed. The court on appeal reversed judgment for plaintiffs, holding the exclusion of defendant's evidence that the contractor was informed of the contents of the pipe and the dangers incident thereto to have been error:

"If there was a breach of duty to the workmen it was DiGiovanni's and not appellant's. . . . Defendant performed its duty when it gave notice to DiGiovanni ; it would be unreasonable to require warning to every sub-contractor and laborer who entered the premises, on the theory that it was appellant's duty to foresee that the contractor would not perform his duty and so permit the work to be done improperly." 6

The court added that it was plaintiff's burden to prove that defendant did not warn the contractor of the dangerous pipe that caused the injury, and since he had failed to do so judgment should be entered for defendant. ${ }^{7}$ It reasoned that imposition of this burden on plaintiff would not be unreasonable since testimony by the contractor concerning instructions given by the possessor would be as available to the plaintiff as to the defendant. ${ }^{8}$

3. Newingham v. J. C. Blair Co., 232 Pa. 511, 81 At1. 556 (1911).

4. Id. at 516, 81 At1. at 558.

5. $339 \mathrm{~Pa}$. 33, 13 A.2d 19 (1940).

6. $339 \mathrm{~Pa}$. at $41,13 \mathrm{~A} .2 \mathrm{~d}$ at 23 .

7. Cf. Pennsylvania Util. Co. v. Brooks, 229 Fed. 93 (3d Cir. 1916) (recognized that the duty to warn of dangerous conditions could be delegated but put the burden on defendant to prove that the warning to the independent contractor revealed the exact nature of the danger).

8. In Straight v. B. F. Goodrich Co., 354 Pa. 391, 47 A.2d 605 (1946), the Valles rule was held inapplicable since plaintiff sustained his burden of proving that defendant failed to warn the contractor of the latent dangerous condition that caused the injury. Accord, Schon v. Scranton-Springbrook Water Serv. Co., 381 Pa. 148, 112 A.2d 89 (1955). 
The Valles doctrine has been applied by the Pennsylvania courts to relieve a possessor of liability for this type of injury only twice since the 1940 decision. $^{2}$ The first of these decisions, Engle v. Reider, ${ }^{10}$ involved an employee of an independent contractor who was killed by fumes. The fumes had accumulated in the attic of defendant's two-story commercial building from a heater installed without a vent, the installer having recommended to defendant that a vent was necessary. The court found no error in the trial court's instruction to the jury that plaintiff had the burden of proving that defendant failed to warn the contractor of the condition and that the contractor did not know of the condition in the event no warning was given. ${ }^{11}$ In thus affirming the second part of the charge, it would seem that the Engle court not only followed the Valles rule on delegability and burden of proof, but further established that the possessor of land need not even warn the contractor if the latter discovers the condition himself.12

The second case to relieve a possessor of liability under the Valles rule was Grace v. Henry Disston \& Sons, Inc. ${ }^{13}$ A contractor was engaged by the defendant corporation to move heavy machinery from one location in defendant's building to another. Steel bars previously had been stacked in a corner near the existing location of the machinery and while the contractor's men were attempting to move a machine vibrations set up by defendant's machinery operating in other parts of the building caused the bars to fall on the plaintiff. The court reiterated the rule that the possessor of land has merely the duty to warn the contractor of the condition and went on to state that the defendant did not have to give any warning where the contractor knew of the bars and the vibrations. ${ }^{14}$

Recent Pennsylvania cases have refused to apply the Valles rule. Generally speaking these recent decisions may be grouped into two types of factual situations: (1) those where the dangerous condition involved the use of electricity, ${ }^{15}$ and (2) those where the danger was created by

9. The Valles rule was followed in several other cases by federal courts applying Pennsylvania law in diversity of citizenship cases. See, e.g., Linker v. Container Corp., 96 F. Supp. 911 (E.D. Pa. 1951), where recovery was denied the employee of a contractor who was injured when he fell through a tarred-over sky light while working on the roof of defendant's building. The evidence showed that the contractor knew of the danger but failed to warn the plaintiff, and the court held that it was not error to instruct the jury that the defendant was under no duty to warn an independent contractor with knowledge of the danger.

10. $366 \mathrm{~Pa} .411,77$ A.2d 621 (1951).

11. $366 \mathrm{~Pa}$. at $416,77 \mathrm{~A} .2 \mathrm{~d}$ at 624 .

12. The dissenting opinion expressed the view that the Valles doctrine should not be extended to this case since the dangerous condition was neither a necessary or proper one as it had been in the Valles case.

13. $369 \mathrm{~Pa} .265,85$ A.2d 118 (1952).

14. $369 \mathrm{~Pa}$. at $272,85 \mathrm{~A} .2 \mathrm{~d}$ at 119.

15. Cooper v. Heintz Mfg. Co., 385 Pa. 296, 122 A.2d 699 (1956). See also Stark v. Lehigh Foundries, Inc., $388 \mathrm{~Pa} 1,130 \mathrm{~A} .2 \mathrm{~d} 123$ (1957) (Court allowed recovery by the employee of a contractor injured when the crane on which he was a helper became electrified by a power line while unloading railroad cars on defendant's property, notwithstanding the fact that the contractor knew of the danger of the lines but failed to warn plaintiff of the danger or to provide the crane with a ground.). See cases cited note 38 infra. But cf. Myers v. Edison Elec. Illuminating Co., $225 \mathrm{~Pa}$. 387, 74 At1. 223 (1909). 
activity of defendant and his personnel as distinguished from a passive condition such as a pipe filled with ammonia or a loft containing deadly fumes. ${ }^{16}$ The clearest illustration of the Pennsylvania court's refusal to apply the $V$ alles rule to cases involving electricity is Cooper v. Heintz Mfg. Co. In this case defendant company engaged an independent contractor to construct a building around a transformer tower which supplied electricity to defendant's plant. Initially the transformer was turned off, but before the construction was completed the current was restored for defendant's operations. The court rejected defendant's contention that it was relieved from liability for the injury sustained by an employee of the contractor who came in contact with the transformer, by reason of a warning to the contractor that the transformer was to be reactivated. The Valles decision was held inapplicable on the ground that in this case the defendant retained "control" over the dangerous condition, the proof of control being that the transformer was supplying electricity to the defendant's plant while the contractor was still working on the building. ${ }^{17}$ The other situation in which courts applying Pennsylvania law have held the Valles rule inapplicable can best be illustrated by the case of Kakias $v$. United States Steel Co., ${ }^{18}$ which involved an injury to the employee of a contractor caused by the starting of machinery without warning in defendant's plant where he was working. The defendant contended that the contractor had been fully apprised of the dangers incident to the continued operation of the machinery in the plant, but the court distinguished the Valles decision by pointing out that the plaintiff was not injured by an "unsafe condition" and therefore the rule was not applicable. ${ }^{19}$

The defense that the plaintiff must prove that the contractor was not warned of the dangerous condition which caused injury to one of his employees has been raised in jurisdictions other than Pennsylvania on very few occasions..$^{20}$ An early New Jersey case, Sommer v. Public Serv. Corp., ${ }^{21}$ held plaintiff's complaint not to be defective merely because it failed to allege that the plaintiff's employer, an independent contractor, had not been warned that wires on defendant's roof where the work was to be performed were uninsulated. The court wrote that "if the contractor knew

16. Kakias v. United States Steel Co., 214 F.2d 434 (3d Cir. 1954). See also cases cited note 40 infra.

17. Cooper v. Heintz Mfg. Co., $385 \mathrm{~Pa} .296,301,122$ A.2d 699, 702 (1956). It is difficult to see how the continued supply of ammonia through the pipe in Valles constitutes any less "control" than was found by the court in Cooper. However, the cases are distinguishable on other grounds. See text at note 37 infra.

18. 214 F.2d 434 (3d Cir. 1954).

19. 214 F.2d at 436.

20. A partial explanation of the infrequency of decisions on this point may be found in the provisions in workmen's compensation statutes making the possessor the "statutory employer" of the injured employee if the work which the contractor performs is work which this employer, or employers in similar businesses, would ordinarily do through employees. In this situation the possessor would normally be immune from common-law suit. 1 LARSON, WORKMEN's COMPENSATION LAW \& 49.12 (1952).

21. 79 N.J.L. 349, 75 At1. 892 (Sup. Ct. 1910). 
the danger and failed to warn decedent he became also a tort-feasor, but that would not relieve the defendant from liability." 22 The result is consistent with the Pennsylvania cases involving electricity, as for example the Cooper decision. ${ }^{23}$ In a more recent New Jersey case, Farrell $v$. Diamond Alkali Co., ${ }^{24}$ an employee of a contractor was injured by chrome dust which filled the air in defendant's plant. The contract for repair of the plant specifically noted the danger of breathing chrome dust and provided that the contractor should provide his employees with protective equipment, but he failed to do so. Despite the warning given to the contractor, the court held that the issue of defendant's negligence in failing to warn the plaintiff directly was properly submitted to the jury. The court relied heavily on the fact that the plaintiff had reported to defendant's plant doctor at the first sign of ill effects and the latter failed to mention the cause of the illness or to instruct plaintiff not to continue working in the plant without protective equipment. ${ }^{25}$ Defendant's personnel knew that the contractor had failed to safeguard his employees and they had ample opportunity to warn plaintiff directly when he reported for treatment. The court, however, went on to say that it recognized "that notice to a reputable independent contractor ought ordinarily be deemed sufficient" to relieve the defendant of liability. ${ }^{26}$

A recent Texas decision apparently adopted the $V$ alles rule. In Texas Elec. Serv. Co. v. Holt ${ }^{27}$ an employee of a contractor was fatally injured by coming in contact with electrical wires while working on defendant's land. Defendant notified the contractor that the wires were to be put into use but no warning was given to plaintiff. In reversing judgment for plaintiff and dismissing the case, the court stated that defendant was "not legally required to notify each employee of the independent contractor" since "it is seldom an employer knows the employees of his independent contractor" and cannot be held to foresee that the warning will not be passed on to the individual employees. ${ }^{28}$ However, great weight was given to the fact that the contractor told defendant that work in the area where the injury occurred was completed and therefore the invitation to plaintiff had been exceeded.

The only other jurisdictions in which cases have been discovered dealing with the delegation of the duty to warn the employee of an independent contractor of latent dangerous conditions are California, ${ }^{29}$ Minnesota, ${ }^{30}$

22. 79 N.J.L. at 351,75 At1. at 893.

23. See text at note 15 supra.

24. 16 N.J. Super. 163, 83 A.2d 900 (App. Div. 1951).

25. 16 N.J. Super. at 169,83 A.2d at 903.

26. Ibid.

27. 249 S.W.2d 662 (Tex. Civ. App. 1952).

28. $I d$. at $666-67$.

29. Sullivan v. Shell Oil Co., 234 F.2d 733 (9th Cir. 1956) ; Dobbie v. Pacific Gas \& Elec. Co., 95 Cal. App. 781, 273 Pac. 630 (1928).

30. Smith v. Twin City Rapid Transit Co., 102 Minn. 4, 112 N.W. 1001 (1907). 
and New Hampshire. ${ }^{31}$ In all of the cases arising in these jurisdictions the contention that warning to the contractor should be adequate was specifically rejected. These cases, with one exception, ${ }^{32}$ involved electricity and the results reached are, therefore, consistent with the Cooper and similar decisions in Pennsylvania. ${ }^{33}$

In all the above cases, analysis proceeds from the assumption that because the employee is on the premises under an invitation from the possessor and his presence is of economic benefit to the possessor, the possessor is under a duty to use reasonable care to see that the employee is not injured by latent dangers. ${ }^{34}$ The problem is to determine whether and in what circumstances reasonable care as a matter of law should require only that the possessor warn the contractor of the danger. Initially a distinction is properly made between those situations in which the employee will be able to proceed with his work safely if the danger is made known to him,,$^{35}$ and those situations in which mere knowledge that a danger is present will not be sufficient to permit the employee to encounter it without an unreasonable risk of injury. ${ }^{36}$ This latter situation is illustrated by the dangers which were present in the Cooper and Kakias cases. In Cooper, ${ }^{37}$ even if the contractor had conveyed the information to his employees that the transformer which was being enclosed had been returned to operation, the danger of arcing made it virtually impossible for the plaintiff to complete the enclosure safely. ${ }^{38}$ Similarly, in Kakias, ${ }^{39}$ the plaintiff was required to work near the machinery in defendant's plant, and a detailed warning as to the risks involved would not have enabled him to avoid injury

31. Stevens v. United Gas \& Elec. Co., 73 N.H. 159, 60 At1. 848 (1905).

32. Sullivan v. Shell Oil Co., 234 F.2d 733 (9th Cir. 1956).

33. See text at note 15 supra.

34. This accords with the Restatement view and that of most prominent writers on tort law. E.g., James, Tort Liability of Occupiers of Land: Duties Oved to Licensees and Invitees, 63 YALE L.J. 605, 615 (1954).

35. Under the Restatement of Torts view the "possessor of land is subject to liability for bodily harm caused to business visitor by a natural or artificial condition thereon if, but only if, he (a) knows, or by the exercise of reasonable care could discover" the latent dangerous condition and fails "(i) to make the condition reasonably safe, or (ii) to give a warning adequate to enable them to avoid the harm." 2 RESTATEMENT, TORTs \& 343 (1934). It would seem that the Restatement thereby takes the position that in all cases of injury by a dangerous condition a warning to the injured party is sufficient to relieve the possessor of land from liability. 2 HARPER \& JAMES, TORTS $\$ 27.13$ (1956).

36. See 2 HARPER \& JAMES, op. cit. supra note 35 , \& 27.13; Prosser, TorTs $\$$ 78 (2d ed. 1955). See also McCracken v. Curwensville Borough, $309 \mathrm{~Pa} .98,163$ Atl. 217 (1932) (plaintiff's knowledge of ice held not to relieve defendant of liability).

37. See text at note 15 supra.

38. Dicta in two recent federal court cases applying Pennsylvania law support the proposition that under the law of that state a warning does not necessarily relieve the possessor from liability to a contractor's employee injured by the use of electricity on the premises. Giannone v. United States Steel Corp., 238 F.2d 544 (3d Cir. 1956); Hamilton v. United States, 143 F. Supp. 179, 182 (W.D. Pa. 1956).

39. See text at note 18 supra. 
when a machine was started without warning by one of defendant's employees. ${ }^{40}$ In situations where a warning directly to the employee would not reasonably protect him from injury the courts have correctly refused to apply the $V$ alles rule. If a warning directly to the employee is inadequate, it cannot be argued that a warning to the contractor should affect the possessor's liability. For the possessor to fulfill his obligations to the contractor's employee nothing short of elimination of the danger should suffice. 11

Where the Valles rule has been applied to absolve a possessor from liability for injury to a contractor's employee the result has been justified on the grounds that the possessor is reasonable in relying on the contractor to pass the warning on to his employees and that the possessor generally has no opportunity to warn the employee directly. ${ }^{42}$ In somewhat similar contexts this rationale is applied to permit delegation of a duty owed to a third person. In determining the liability of a lessor to the invitees of his tenant for injuries caused by latent dangerous conditions on the premises the rule normally applied is that the lessor must warn the lessee of known dangerous conditions existing at the time of the lease. ${ }^{43}$ However, once the lessor has performed this duty it is the tenant's duty to inform persons entering the premises by his invitation or permission of the dangerous condition.4 The lessor is normally not present to warn persons likely to encounter the dangers and he has no way of knowing what persons the lessee will invite to enter. Similarly, in the Valles situation the posssessor normally does not supervise the conduct of the work and has no way of knowing the identity or number of employees the contractor will choose to use.

So also the possessor of land may in many cases relieve himself of liability to third persons for injuries caused by work being negligently performed on his premises by hiring an independent contractor to perform the work. .5 $^{45}$ Here again the rationale is similar to that used by the courts applying the Valles rule. If the possessor has used care in selecting a reputable contractor he may assume that due care will be used in the performance of the work. Normally also the person who employs a contractor does not have the specialized knowledge to permit him to prescribe

40. See 2 RESTATEMENT, ToRTs \& 341 (1934). See also Brown v. American Steel Foundries, $272 \mathrm{~Pa} .231,116$ At1. 546 (1922); Craig v. Riter-Conley Mfg. Co., 272 Pa. 219, 116 Atl. 167 (1922); Reed v. Pittsburgh, C. C. \& St. I. Ry., 243 Pa. 562, 90 At1. 359 (1914); cf. Rugart v. Keebler-Weyl Baking Co., 277 Pa. 408, 121 At1. 198 (1923).

41. See note 36 sitpra.

42. $339 \mathrm{~Pa}$. at $41,13 \mathrm{~A} .2 \mathrm{~d}$ at 23 . See aiso Myers v. Edison Elec. Illuminating Co., $225 \mathrm{~Pa} .387,389,74$ At1. 223, 224 (1909).

43. Cutter v. Hamlen, 147 Mass. 471, 18 N.E. 397 (1888); Rhoades v. Seidel, 139 Mich. 608, 102 N.W. 1025 (1905); Charlton v. Brunelle, 82 N.H. 100, 130 Atl. 216 (1925) ; Cesar v. Karutz, 60 N.Y. 229 (1875). In some jurisdictions the lessor is under a duty to warn the lessee of discoverable as well as known dangerous conditions. See, e.g., Ames v. Brandvold, 119 Minn. 521, 138 N.W. 786 (1912).

44. 1 TIFFanY, LANDLORD AND TENANT $\S 96(\mathrm{~b})$ (1910). See also Eldredge, Landlord's Tort Liability for Disrepair, 84 U. PA. L. REv. 467 (1936).

45. Prosser, ToRTs $\$ 64$ (2d ed. 1955). 
the manner in which the work should be conducted and he does not supervise the conduct of the contractor's employees.

Probably the most persuasive argument against accepting warning to the contractor as an absolute defense rather than as merely a factor which the jury should consider in determining whether the possessor used reasonable care is that a cheap and efficient alternative to warning to the contractor may be open to the possessor. For example, in the Valles case the defendant bank could have easily placed a warning sign in the vicinity of the contractor's operations marking the ammonia pipe. Similarly, in Engle a sign giving notice of the dangerous fumes would have conveyed the warning to the contractor's employees with little more effort than it took to describe the dangers to the contractor. ${ }^{46}$ It was probably this type of reasoning which led the court in Farrell, upon hearing evidence that defendant's doctor had failed to warn plaintiff of his need for protective equipment, to let the case go to the jury, despite a warning to the contractor. All this is to suggest that even though in some cases a warning to the contractor and reliance on him to relay the warning to his employees may be reasonable, general application of a rule making warning a defense may not be sufficiently discriminating: too many faulty defendants may be relieved of liability. On the other hand, making warning to the contractor merely another factor to be considered by the jury in determining if the possessor used reasonable care under the circumstances does not account for the fact that sympathetic juries, anxious to compensate injured plaintiffs, may not afford warning its due weight. A possible compromise, though admittedly a difficult one to administer, is to permit the court in its sound discretion to apply the Valles rule when satisfied as a matter of law that no cheap, efficient alternative to warning to the contractor was available to the prissessor.

46. Further the possessor will be able to seek indemnity from the contractor for his failure to pass the warning on to the employee. 2 LARSON, WORKMEN's COMPENSATION LAW \& 76.43 (1952). However, the recovery by the possessor from the contractor may be limited to the amount the contractor would be liable to the employee under workmen's compensation. E.g., Cooper v. Heintz Mfg. Co., $385 \mathrm{~Pa}$. 296, 122 А.2d 699 (1956). 